\title{
Application of Floating Photovoltaic Energy Generation Systems in South Korea
}

\author{
Sun-Hee Kim ${ }^{1}$, Soon-Jong Yoon ${ }^{1}$, Wonchang Choi ${ }^{2, *}$ and Ki-Bong Choi ${ }^{2}$ \\ 1 Department of Civil Engineering, Hongik University, Seogang-dong, Mapo-gu 04066, Korea; \\ sunnys82@hanmail.net (S.-H.K.); sjyoon@hongik.ac.kr (S.-J.Y.) \\ 2 Department of Architectural Engieering, Gachon University, Seongnam-si, Gyeonggi-do 13120, Korea; \\ kbchoi@gachon.ac.kr \\ * Correspondence: wchoi@gachon.ac.kr; Tel.: +82-10-9102-4555
}

Academic Editors: Jiawei Gong and Qiquan Qiao

Received: 31 October 2016; Accepted: 29 November 2016; Published: 17 December 2016

\begin{abstract}
In order to mitigate air pollution problems caused mainly by the excessive emission of carbon dioxide, in 2012, the South Korean government decided to introduce a renewable portfolio standards (RPS) program that requires electricity providers to gradually increase their production of renewable energy. In order to meet the government's target through this RPS program, electricity providers in Korea have looked to various types of new and renewable energy resources, such as biomass, wind, and solar. Recently, floating photovoltaic (PV) systems have attracted increased interest in Korea as a desirable renewable energy alternative. This paper provides a discussion of recent research into floating PV systems and the installation of floating PV power plants in Korea from 2009 to 2014. To date, thirteen floating PV power plants have been installed in Korea, and several plans are underway by many different organizations, including government-funded companies, to install more floating PV power plants with various generation capacities. These building trends are expected to continue due to the Korean government's RPS program.
\end{abstract}

Keywords: renewable energy; renewable portfolio standards (RPS) program; floating photovoltaic (PV) power plant; installation

\section{Introduction}

The market for photovoltaic (PV) energy in South Korea is expanding rapidly due to the Korean government's renewable portfolio standards (RPS) program [1]. In 2012, the Korean government decided to introduce this RPS program, which requires electricity providers to gradually increase the amount of renewable energy through "the act on the promotion of development, use and dissemination of new and renewable energy" [2]. The capacity required for the energy production of new and renewable energy has increased gradually from $2 \%$ total energy production in 2012 to a target of $10 \%$ total energy production in 2022. In order to meet the government's target through the RPS program, electricity providers in Korea have employed various types of new and renewable energy resources, such as biomass, wind, solar, bioenergy, and geothermal energy.

Recently, floating PV energy systems as generators of renewable energy have attracted increased interest from energy providers in Korea. The Korean peninsula is a small land area, relatively speaking, and is surrounded by the sea on three sides. Therefore, floating PV energy systems constitute a desirable alternative to many of the other available renewable energy resources.

According to previous research [3], floating PV energy systems offer several advantages over systems installed on land. First, because floating PV energy systems are installed on water, the land can be conserved and used for other purposes. Second, floating PV energy systems provide energy 
generation efficiency because the ambient temperature of water is relatively low. Finally, evaporation from the water's surface may be reduced when a floating PV energy system is installed in a reservoir.

Trapani and Redón Santafé (2014) [4] discussed examples of floating PV energy generation systems that were installed from 2007 to 2013 worldwide. The total number of installations of floating PV power plants in the world was 19 from 2007 to 2013. During this period, various types of floating PV power plants were installed in the United States, Italy, Spain, France, Korea, and several other countries. However, research studies about the installations in Korea are lacking. Therefore, the existing floating PV power plants and new floating PV power plants under construction in Korea need to be introduced to the literature to gain a better understanding of current research efforts. The purpose of this paper is to provide a discussion of the research related to floating PV energy systems and the installation of floating PV power plants in Korea from 2009 to 2014. The floating PV power plants that were installed from 2009 to 2010 are research-based, and the ones installed from 2011 to 2014 are commercial installations.

\section{Floating PV Energy Systems in Korea: 2009-2010}

Table 1 provides a summary of the floating PV energy systems that were installed in Korea from 2009 to 2010. The first floating PV energy system was installed in the Seoungmun Reservoir (Dangjin-si, Chungcheongnam-do) in 2009, as pictured in Figure 1 [5]. This system has nine PV panels with $2 \mathrm{~kW}$ generation capacity. Although this particular system was installed for research purposes, results of studies of the system had not been presented in the literature until 2013 [6]. However, three different types of floating PV systems were also installed in Korea in 2009, and studies of them began immediately and have been available in the literature since 2009.

Table 1. Floating photovoltaic (PV) energy systems in Korea: 2009-2010.

\begin{tabular}{|c|c|c|c|c|}
\hline Installation Date & Location & Capacity & $\begin{array}{c}\text { Material for the PV Panel } \\
\text { Supporting Structure }\end{array}$ & $\begin{array}{c}\text { Design } \\
\text { Concept }\end{array}$ \\
\hline 2009 & Seongmun Reservoir (Dangjin-si) & $2 \mathrm{~kW}$ & Steel & $\mathrm{N} / \mathrm{A}^{1}$ \\
\hline 2009 & Juam Dam (Suncheon-si) & $2.4 \mathrm{~kW}^{1}$ & Polyethylene & $\mathrm{N} / \mathrm{A}^{1}$ \\
\hline October 2009 & $\begin{array}{l}\text { Homyeong Lake in } \\
\text { Cheongpyeong hydro power } \\
\text { plant (Gapyeong-gun) }\end{array}$ & $5.2 \mathrm{~kW}$ & FRP & $\mathrm{N} / \mathrm{A}^{1}$ \\
\hline December 2009 & Sea site (Tongyeong-si) & $3.26 \mathrm{~kW}$ & FRP & $\mathrm{ASD}^{2}$ \\
\hline December 2010 & Sea site (Tongyeong-si) & $3.22 \mathrm{~kW}$ & FRP & $\mathrm{ASD}^{2}$ \\
\hline
\end{tabular}
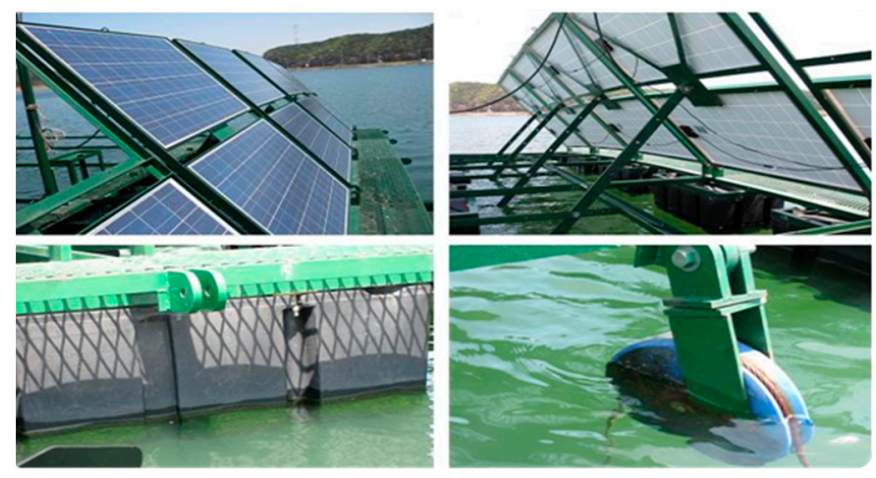

Figure 1. Floating PV energy system at the Seongmun Reservoir.

These additional systems that were installed in 2009 include the Korea Water Resources Corporation (known as 'K-water') floating PV energy system with $2.4 \mathrm{~kW}$ generation capacity at the Juam Dam (Suncheon-si, Jeollanam-do), as shown in Figure 2 [5]. The purpose of K-water's first project was to investigate the possibility of solar energy harvesting using a floating PV energy system. 


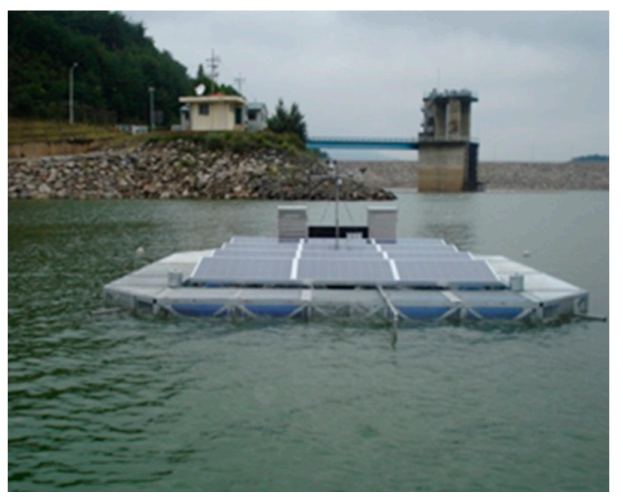

Figure 2. Floating PV energy system at the Juam Dam.

Another floating PV energy system with $5.2 \mathrm{~kW}$ generation capacity was installed at Homyeong Lake (at the Cheongpyeong hydro-power plant) in October 2009 by the Korea Southern Power Corporation (KOSPO), as shown in Figure 3.

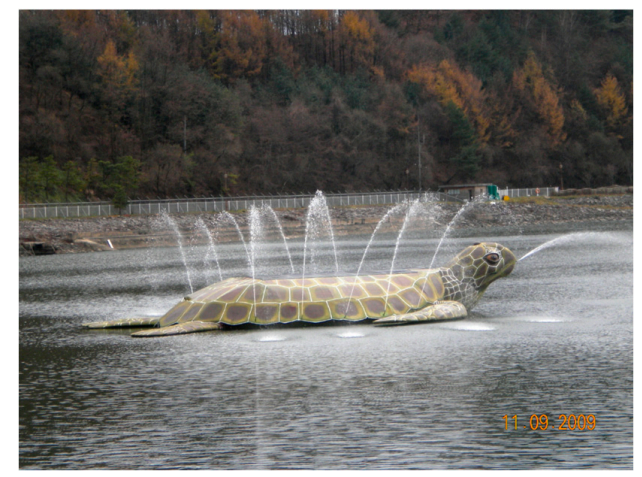

Figure 3. Floating PV energy system at Homyeong Lake [7].

This floating PV energy system, shaped like a turtle, is made of fiber-reinforced plastic (polymer) (FRP) material and was planned and installed to promote the utilization of renewable energy systems. The electricity produced by this system is used as a power source for the streetlights around the lake.

The third 2009 floating PV system was the first government-funded research project (NRP) in Korea for the development of floating PV systems and was initiated by the research team at Hongik University in December 2008 [8]. During the study period, the research team developed and installed two prototypes of a floating PV energy system. The first had $16 \mathrm{PV}$ panels with $3.68 \mathrm{~kW}$ generation capacity and was installed in Puksin-Bay, Tongyeong-si, Gyeongsangnam-do, Korea, in December 2009, as shown in Figure 4 [1,3,9,10].

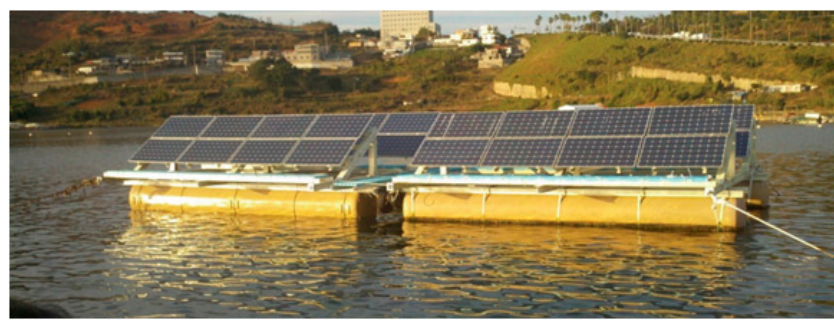

Figure 4. Floating PV energy system at Puksin-Bay, Tongyeong-si. 
The second prototype had $14 \mathrm{PV}$ panels with $3.22 \mathrm{~kW}$ generation capacity and was installed at Punghwa-ri, Tongyeong-si, Gyeongsangnam-do, Korea, in December 2010, as shown in Figure 5 [5].

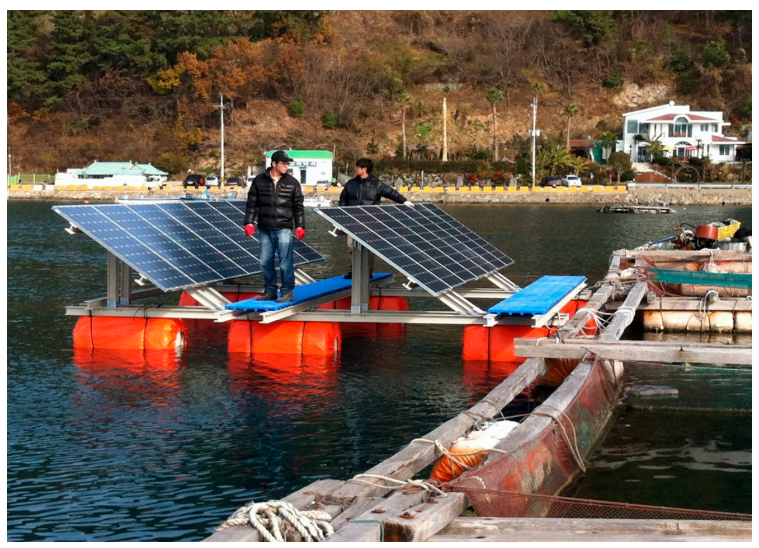

Figure 5. Floating PV energy system at Punghwa-ri, Tongyeong-si.

These two prototype structures were made of FRP material produced by a pultrusion process. This FRP material was selected due to its high resistance to corrosion and its light weight. In addition, unlike the aforementioned systems that were installed on a reservoir or lake, these two prototypes were installed in the sea. In addition, they were designed using systematic design methods in accordance with relevant standard specifications. The design methods of the others systems installed from 2009 to 2010 are not reported in the literature.

\section{Floating PV Energy Systems in Korea: 2011-2014}

Table 2 provides a summary of the installations of floating PV systems in Korea from 2011 to 2014. As discussed in Section 2, several floating PV system projects had been undertaken from 2009 to 2010. However, all of these projects were carried out for research purposes, so they were designed and installed with small capacities. From 2011, however, floating PV power plants on a relatively large scale were installed by K-water, the Korea Rural Community (KRC) Corporation, the Korea East-West Power (EWP) Corporation, and other companies. For example, a floating PV power plant with 100 $\mathrm{kW}$ generation capacity was installed at the Hapcheon Dam (Hapcheon-gun, Gyeongsangnam-do) in October 2011, as shown in Figure 6.

Table 2. Floating PV energy systems in Korea: 2011-2014.

\begin{tabular}{|c|c|c|c|c|c|}
\hline Installation Date & Location & $\begin{array}{l}\text { Tracking } \\
\text { Type }\end{array}$ & $\begin{array}{l}\text { Generation } \\
\text { Capacity }\end{array}$ & $\begin{array}{l}\text { Material for the PV Panel } \\
\text { Supporting Structure }\end{array}$ & $\begin{array}{l}\text { Design } \\
\text { Concept }\end{array}$ \\
\hline October 2011 & Hapcheon Dam (Dangjin-si) & Fixed & $100 \mathrm{~kW}$ & Steel/Aluminum/FRP & $\mathrm{ASD}^{2}$ \\
\hline July 2012 & Hapcheon Dam (Dangjin-si) & Fixed & $500 \mathrm{~kW}$ & Aluminum & $\mathrm{N} / \mathrm{A}^{1}$ \\
\hline 2012 & Reservoir (Cheongju-si) & FTCC & $30 \mathrm{~kW}$ & Steel & $\mathrm{N} / \mathrm{A}^{1}$ \\
\hline December 2012 & Reservoir (Gochang-gun) & Fixed & $30 \mathrm{~kW}$ & FRP & $\mathrm{ASD}^{2}$ \\
\hline June 2013 & $\begin{array}{l}\text { Cooling water intake } \\
\text { channnel (Dangjin-si) }\end{array}$ & Fixed & $1000 \mathrm{~kW}$ & FRP & $\begin{array}{c}\text { ASD }^{2} \\
\text { LRFD }^{3}\end{array}$ \\
\hline July 2013 & Reservoir (Naju-si) & Fixed & $30 \mathrm{~kW}$ & Polyethylene & $\mathrm{N} / \mathrm{A}^{1}$ \\
\hline December 2013 & $\begin{array}{l}\text { Hapcheon Dam } \\
\text { (Hapcheon-gun) }\end{array}$ & $\begin{array}{l}\text { Tracking } \\
\text { type }\end{array}$ & $100 \mathrm{~kW}$ & FRP & $\mathrm{ASD}^{2}$ \\
\hline August 2014 & Reservoir (Ansung-si) & $\begin{array}{l}\text { Tracking } \\
\text { type }\end{array}$ & $465 \mathrm{~kW}$ & Steel & $\mathrm{N} / \mathrm{A}^{1}$ \\
\hline
\end{tabular}

${ }^{1}$ N/A: Not applicable; i.e., design method was not applied (or not known); ${ }^{2}$ ASD: Allowable strength design; LRFD: Load and resistance factor design. 


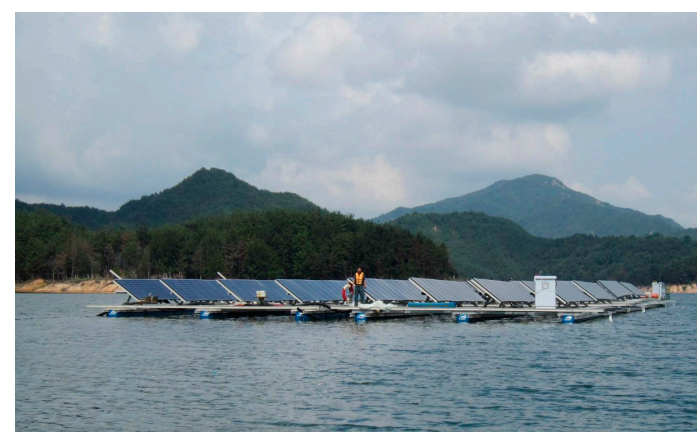

Figure 6. A $100 \mathrm{~kW}$ floating PV energy system at the Hapcheon Dam [11].

After the successful installation of this floating PV power plant with $100 \mathrm{~kW}$ generation capacity, K-water, also installed a $500 \mathrm{~kW}$ floating PV power plant at another site on the Hapcheon Dam in July 2012, as shown in Figure 7 [12]. These two floating PV power plants were installed using design-to-installation technical support provided by the authors.

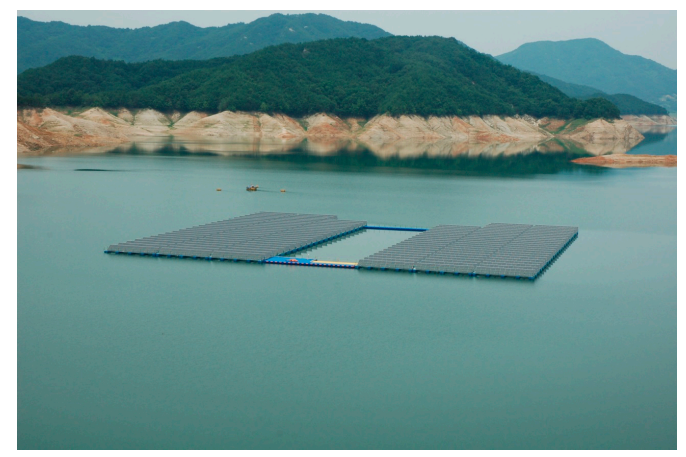

Figure 7. A $500 \mathrm{~kW}$ floating PV energy system at the Hapcheon Dam [11].

K-water also conducted a government-funded research project National Research Project (NRP) for the development of a rotating structure for the tracking-type of floating PV energy system. The tracking type generally is of the form that tracks the position of the sun by rotating the structure. This project was also undertaken with technical guidance from the authors, from the design of the structure's system to the installation of the system, including mooring. The study period of the project was three years, from September 2011 to September 2014. During this project, a tracking-type of floating PV energy system with $100 \mathrm{~kW}$ capacity was installed at the Hapcheon Dam in December 2013, as shown in Figure 8.

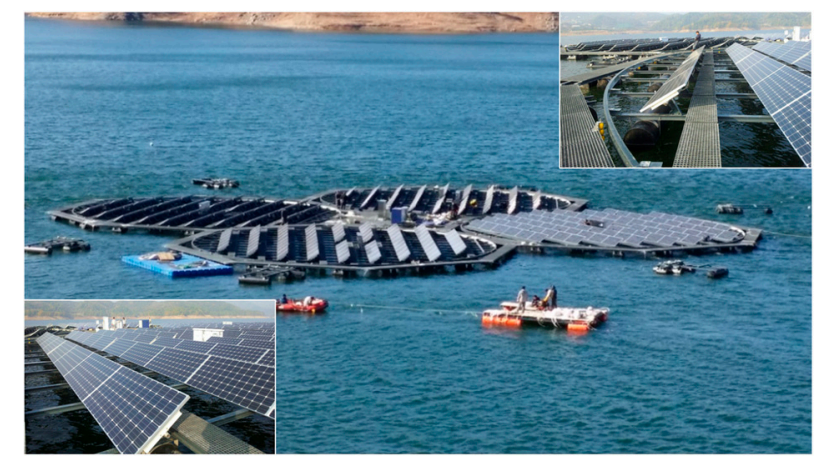

Figure 8. Tracking-type floating PV energy system installed at the Hapcheon Dam. 
It consisted of a four-unit structure with $24.8 \mathrm{~kW}$ generation capacity per unit. The internal rectangularly shaped structure hosts an operating device for rotation and various electrical devices, as shown in Figure 9 [13-15].

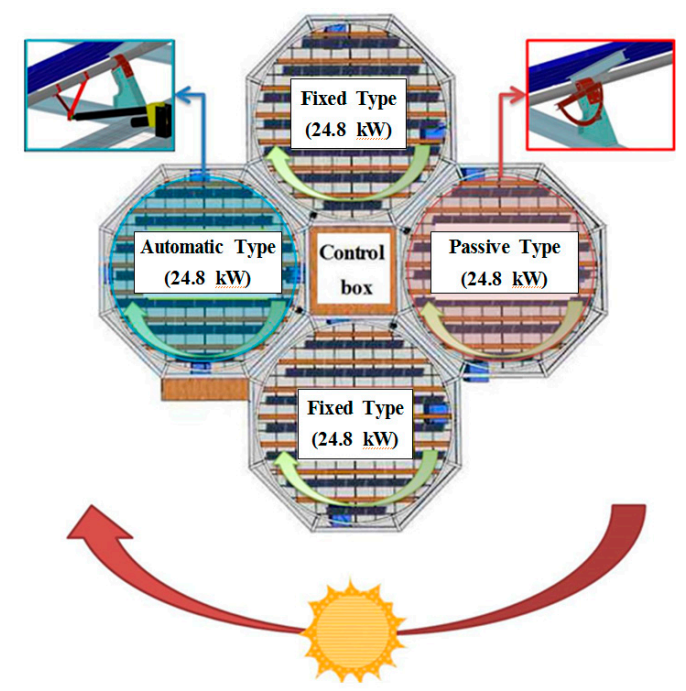

Figure 9. Composition of the tracking-type floating PV energy system installed at the Hapcheon Dam.

In addition, a two-unit structure was installed as fixed units. One of these units served as a passive tracking system to control the angle of the PV panel seasonally, and the other unit served as an automatic tracking system to control the angle of the PV panel with respect to an optical sensor.

In 2012, a floating PV power plant with $20 \mathrm{~kW}$ generation capacity that employs floating tracking cooling concentrator (FTCC) technology was installed in Cheongju-si, as shown in Figure 10.

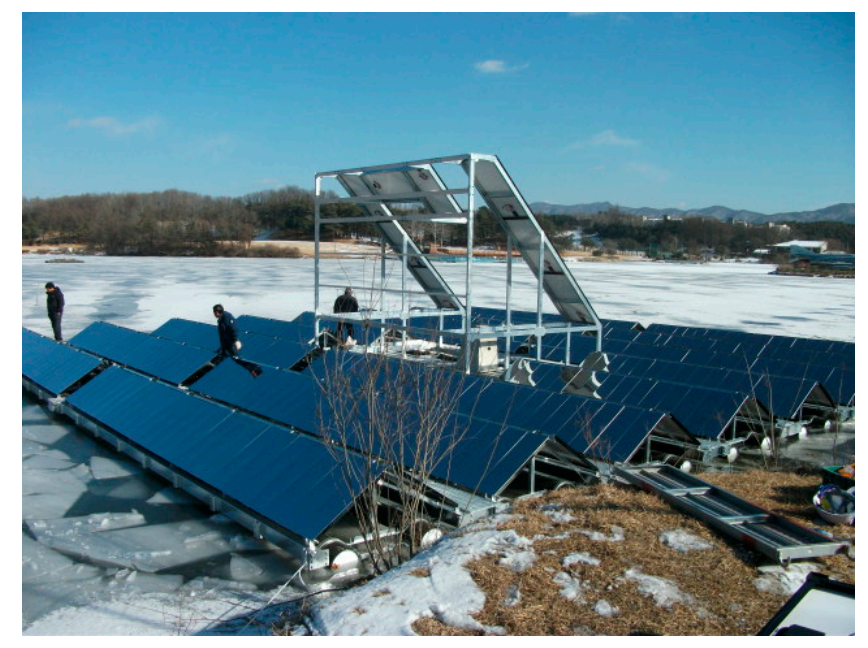

Figure 10. Floating tracking cooling concentrator (FTCC) system at Cheongju-si [16].

This FTCC system was built by Techwin in collaboration with Koinè Multimedia and Scienza Industria Tecnologia (SCINTEC). In December 2012, the KRC Corporation installed a $30 \mathrm{~kW}$ floating PV power plant at the Cheongho Reservoir (in Buan-myeon, Gochang-gun, Jeollabuk-do), as shown in Figure 11. 


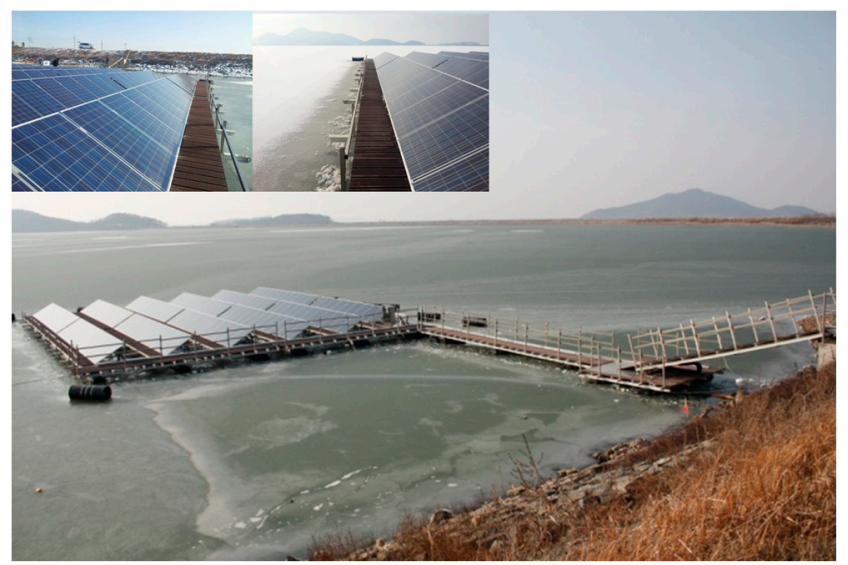

Figure 11. A $30 \mathrm{~kW}$ floating PV power plant at the Cheongho Reservoir.

In addition, the KRC Corporation installed a $30 \mathrm{~kW}$ floating PV power plant at the Baengnyong Reservoir (in Dasi-myeon, Naju-si, Jeollanam-do) in July 2013, as shown in Figure 12.

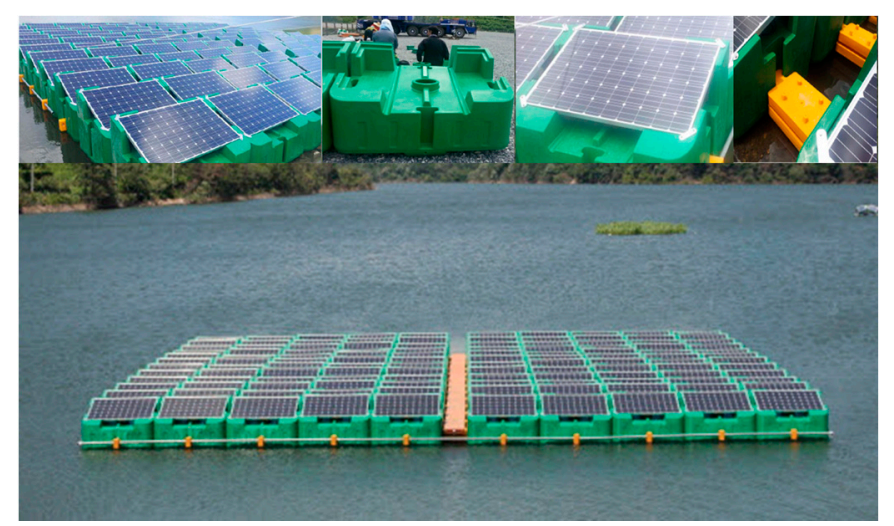

Figure 12. A $30 \mathrm{~kW}$ floating PV power plant at the Baengnyong Reservoir.

In June 2013, the first 1 MW class floating PV power plant in Korea was introduced at Dangjin-si, Chungcheongnam-do. The Korea EWP Corporation installed this floating PV power plant at the cooling water intake channel at the thermoelectric power plant, as shown in Figure 13.

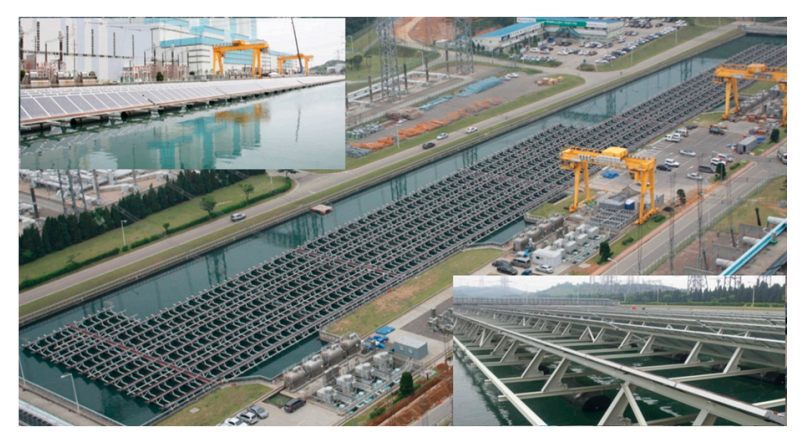

Figure 13. A $1 \mathrm{MW}$ floating PV power plant at Dangjin-si.

To date, this floating PV power plant has the largest generation capacity in Korea. This system was designed and installed under guidance provided by the authors.

The most recent rotation-type floating PV power plant in Korea was installed at Geumgwang Reservoir (in Ansung-si, Gyeonggi-do) in August 2014 by the KRC Corporation, as shown in Figure 14. 


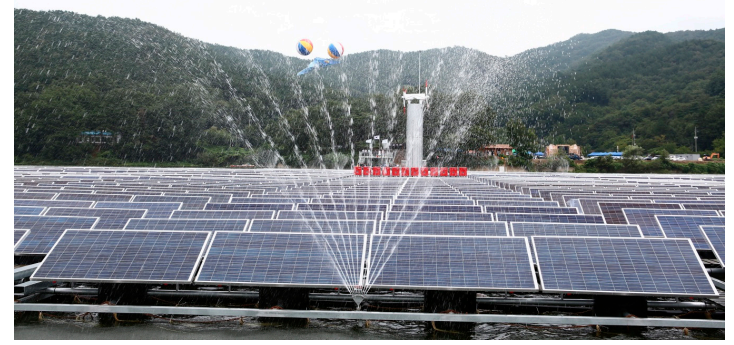

Figure 14. A $465 \mathrm{~kW}$ rotation-type floating PV power plant at the Geumgwang Reservoir [17].

This floating PV power plant has $465 \mathrm{~kW}$ generation capacity. Although the overall rotation form of this floating PV power plant is similar to that of the floating PV power plant installed by K-water in Hapcheon, there is a significant difference in their rotating principles. The rotation system of the floating PV power plant installed by the KRC Corporation has a center post located at the center of the overall structure in order to fix the post's position in place and serve as the pivotal center of the rotation. The rotating force of the system is provided by a rope anchored on land, whereby two piles are driven into the earth and the rope is connected to the piles. It is easy to construct the rotation system for this type of floating PV power plant. However, it is difficult to apply this principle when the differences in water level due to seasonal changes are significant, as is the case for the floating PV power plant installed by K-water in Hapcheon.

In addition to the floating PV power plants installed to date, several plans for additional floating PV power plants with various generation capacities are underway by many organizations including government-funded companies. These installation trends are expected to continue due to the government's RPS program.

\section{Conclusions}

The review presented in this paper discusses the thirteen floating PV power plants that have been installed in Korea to date. Among them, the floating PV power plants installed before 2011 may be considered as test beds for research purposes. After 2011, commercial floating PV power plants were first introduced by the Korean Power GENCOs in Korea. Based on these trends, in January 2013, the Korean government revised 'Management and operation guidelines for renewable portfolio standards (Notification No. 2013-5 of the Ministry of Knowledge-Economy)'. In accordance with these revised guidelines, the Korean government announced that the renewable energy certificate (REC) value would be 1.5 for floating PV systems, which is the same value as for the building-integrated photovoltaic (BIPV) system from the year 2013. If the government continues to support floating PV power plants, then the installation of floating PV power plants with large capacities, such as multi-megawatt scales, will continue. Therefore, floating PV power generation systems may continue to be front-runners for renewable energy technologies in Korea for the future.

Author Contributions: Soon-Jong Yoon and Ki-Bong Choi contributed to conception and design, and summarized the literatures; Sun-Hee Kim wrote the paper; Wonchang Choi revised the paper critically for important organization and final version to be published.

\section{References}

1. Choi, Y.K. A study on power generation analysis of floating PV system considering environmental impact. Int. J. Softw. Eng. Appl. 2014, 8, 75-84. [CrossRef]

2. The Act on the Promotion of Development, Use and Dissemination of New and Renewable Energy. Available online: http:/ / www.lawnb.com/lawinfo/contents_view.asp?cid=8380981EC73E47D79AF2673FED5B779D \ $\mathrm{T} 1 \backslash$ textbar \{\} $0 \backslash \mathrm{T} 1 \backslash$ textbar \{\} $\mathrm{K}$ (accessed on 29 November 2016). 
3. Lee, Y.G.; Joo, H.J.; Yoon, S.J. Design and installation of floating type photovoltaic energy generation system using FRP members. Sol. Energy 2014, 108, 13-27. [CrossRef]

4. Trapani, K.; Santafé, M.R. A review of floating photovoltaic installation: 2007-2013. Prog. Photovolt. Res. Appl. 2015, 23, 524-532. [CrossRef]

5. Yoon, S.J. Development of Environment Friendly Floating Type Photovoltaic Generation System for the Effective Land Use; Technical Report; Korea Institute of Marine Science \& Technology Promotion: Seoul, Korea, 2011.

6. Joo, H.J.; Lee, N.H.; Lee, S.W. Floating photovoltaic power generation system. Mag. Korean Soc. Adv. Compos. Struct. 2013, 4, 31-39.

7. Korea Southern Power Co., Ltd. (KOSPO). Available online: http://www.kospo.co.kr (assessed on 29 November 2016). (In Korean)

8. Choi, H.; Joo, H.J.; Kim, K.S.; Yoon, S.J. Structural design for the development of the floating type photovoltaic energy generation system. Mater. Sci. Forum 2010, 654-656, 2803-2806. [CrossRef]

9. Nam, J.H. Development of Floating Type Photovoltaic Energy Generation System Using the Pultruded Structural Members. Ph.D. Thesis, Hongik University, Seoul, Korea, 2010.

10. Lee, Y.G.; Joo, H.J.; Nam, J.H.; Yoon, S.J. Modified design of floating type photovoltaic energy generation system. J. Korean Soc. Adv. Compos. Struct. 2010, 1, 19-27.

11. K-Water. Available online: http:/ / www.kwater.or.kr (assessed on 29 November 2016). (In Korean)

12. Choi, Y.K.; Lee, N.H.; Kim, K.J. Empirical research on the efficiency of floating PV systems compared with overland PV systems. In Proceedings of the International Conference on Circuits, Control, Communication, Electricity, Electronics, Energy, System, Signal and Simulation (CES-CUBE 2013), Guam, USA, 18-20 July 2013.

13. Choi, Y.K.; Lee, N.H.; Kim, K.J. A study on major design elements of tracking-type floating photovoltaic systems. Int. J. Smarty Grid Clean Energy 2014, 3, 70-74. [CrossRef]

14. Choi, Y.K.; Lee, Y.G. A study on development of rotary structure for tracking-type floating photovoltaic system. Int. J. Precis. Eng. Manuf. 2014, 15, 2453-2460. [CrossRef]

15. Kim, S.H.; Lee, Y.G.; Seo, S.H.; Joo, H.J.; Yoon, S.J. Structural design and installation of tracking-type floating PV generation system. Compos. Res. 2014, 27, 59-65. [CrossRef]

16. Croatian Center of Renewable Energy Sources. Available online: http://solarserdar.wordpress.com/2012/ 03/03/floating-tracking-cooling-concentrator-ftcc (accessed on 3 March 2012). (In Korean)

17. Korea Rural Community Corporation (KRC). Available online: http://www.ekr.or.kr (assessed on 29 November 2016). (In Korean)

(C) 2016 by the authors; licensee MDPI, Basel, Switzerland. This article is an open access article distributed under the terms and conditions of the Creative Commons Attribution (CC-BY) license (http:/ / creativecommons.org/licenses/by/4.0/). 